\title{
A REGIONÁLIS IDENTITÁS STRUKTURALISTA ÉRTELMEZÉSE
}

\author{
(A Structuralist Approach of the Regional Identity)
}

\author{
BUSKÓ TIBOR LÁSZLÓ
}

\begin{abstract}
Kulcsszavak:
régió regionális identitás humanisztikus földrajz strukturációelmélet kistérségek

Egy leegyszerüsitett értelmezés szerint a regionális kutatások eljárhatnak „objektív” módon, a legkülönfélébb térbeli folyamatok figyelembevételével (a téranalízis szemléletmódja), de tekinthetik a régiót - felvállalva egyfajta szubjektivista elkötelezettséget - az itt élö emberek értékeinek, normáinak, életvilágának produktumaként. A következö tanulmányban amellett érvelünk, hogy a regionális identitás strukturalista értelmezési keretei között ez az, „objektivista” és „szubjektivista” megközelítésmód összeegyeztethetö.
\end{abstract}

\section{A humanisztikus kiindulópont}

A hetvenes évek elejétől, elsősorban angolszász területen kibontakozó, leginkább Anne Buttimer és $Y i$-Fu Tuan nevével fémjelezhető humanisztikus földrajz definíciója a földrajztudomány egyik mértékadó kézikönyvének számító The Dictionary of Human Geography szerint a következö: ,,az emberföldrajzra jellemző megközelítés az emberi tudatosság és cselekvés, az emberi öntudat és az emberi kreativitás központi és aktív szerepével jellemezhető. A humanisztikus földrajz ugyanakkor kísérlet arra, hogy megértsük 'az élet eseményeinek jelentését, értékét és az ember számára való jelentöségét', valamint egy elterjedt nézet arról, hogy mi az emberi személy, illetve mit tud tenni ö."1 (Gregory 1994, 263)

Tuan a következőképp teszi még érzékletesebbé az előbbieket: „a téranalízis müvelöjével szemben, akinek az emberröl szóló leegyszerüsítö feltevésekböl kell kiindulnia, a humanista már a kezdet kezdetén mély elkötelezettséget vállal az emberi természetnek a maga bonyolultságában való megértése mellett." (Tuan 1977, 421) Ez a megjegyzés egyszerre tartalmaz egy negatív, illetve egy pozitív komponenst. Ami a negatív komponenst illeti, a humanisztikus földrajz leginkább az emberi tényező „leegyszerüsítő” (redukcionista/pozitivista) felfogását hirdető „,téranalízis”-sel (spatial analysis) áll szemben. Pozitív oldalról viszont elsőbbséget ad egy alternatív, az embert a maga bonyolultságában szemlélő megközelítésnek. Ebből következően válik a humanisztikus földrajz kulcsfogalmává a „,megértés” (,understanding”). A regionális tudomány művelője inkább „,külső” elméletek segítségével kívánja megmagyarázni a térbeliség bizonyos jellegzetességeit; ez viszont humanisztikus szemszögből egyet jelent azzal, hogy nem történik megértés, vagy ha mégis, akkor nem a világ eredendő 
összetettségének megértése megy végbe. A humanisztikus földrajz megértésének tárgya így csakis az ember mindennapi földrajzi tapasztalatának világa lehet.

A mindennapi földrajzi tapasztalat világának centrális pozíciója szinte törvényszerüen kötelezi el a humanisztikus földrajzot egyfajta fenomenológia, illetve fenomenológiai módszer alkalmazása mellett. A humanisztikus földrajz ,fenomenológiá"-ján azonban - mint ahogy arra kiváló elemzésében John Pickles is rámutat - nem a husserli értelemben vett ,szigorú tudomány”-t kell értenünk. „Ez a fenomenológia nem tekinthetö a husserli projektnek, de nem is annak valamelyik származéka, sokkal inkább egyfajta tudományos realizmus, amely egy elözetes fenomenológiára épül - a fennálló jelenségek leírására úgy, ahogy azok valójában vannak (azaz úgy, ahogy megjelennek). Vagyis, a fenomenológia kantiánus és machiánus fogalmához kanyarodunk el." (Pickles 1985, 44) A mindennapi tapasztalat „leírás”-ának (description) túlhangsúlyozása tehát egyúttal azt is jelenti, hogy a humanisztikus földrajz feno-menológiája mintegy félúton megáll: a mindennapi földrajzi tapasztalat (tudás) konstitúciójának elemzését már nem követi a földrajztudomány tudásának hasonló elemzése. Ami viszont egy olyasféle következményhez vezet, amit Nicholas Entrikin jegyzett meg a humanisztikus földrajzról szóló összefoglaló tanulmányában: „, a humanista geográfusok szerint a mindennapi tapasztalat, illetve a társadalomtudományok müvelöinek erröl alkotott modelljei két szeparált világot alkotnak." (Entrikin 1976, 627)

Ehhez mi azért hozzátehetjük, hogy két, tökéletesen szeparált világról csakis akkor beszélhetnénk mindenfajta fenntartás nélkül, ha a humanisztikus földrajz által feltárt és leírt mindennapi földrajzi tapasztalat sohasem lépne fel azzal az igénnyel, hogy valamilyen mértékben a maga számára elfogadhatóbb irányba befolyásolja a redukcionista/pozitivista tudományt. Azonban hiba lenne ezt állítani. Bár bizonyos helyeken a humanista előszeretettel állítja szembe módszerét a pozitív tudományokkal, néha egyenesen anti-tudományként definiálja önmagát, általában mégis fenntartja a két világ közötti átjárás egy bizonyos lehetőségét. Tuan például egyértelmüen erröl beszél. „Lehet bármilyen értéke a humanista munkáinak a pozitivista számára? Állítom, hogy igen [...] mert felhívhatják a figyelmet az emberi tapasztalat egyes formáira, illetve tisztázhatnak bizonyos ezekkel kapcsolatos problémákat, legalábbis amennyiben azok beilleszthetők a pozitivista saját módszertanába." (Tuan 1977, 421)

Tuan szerint a humanisztikus felfogás értéke világosan megmutatkozik abban, hogy annak egyes elemeit még a pozitivista is beillesztheti saját módszertanába. Azt azonban már nem magyarázza - és a humanisztikus földrajz „szigorú tudományának" hiányában nem is igen magyarázhatja meg -, miképpen is kellene beépítenie a pozitivistának a humanisztikus felfogás eredményeit. Ebből a belátásból a humanisztikus földrajzra nézve két dolog következik. Egyrészröl fel kell adnia univerzális szerepét, másképpen: be kell ismernie, hogy - legalábbis fejlődésének jelenlegi szakaszában - bizonyos feladatokra nem alkalmas, és azokat át kell engednie a pozitív tudományoknak. Másrészről azonban éppen ennek az univerzális szerepnek a feladása járulhat hozzá ahhoz, hogy tisztázza az objektív tudományokhoz való ellentmondásos viszonyát. 
Itt és most csak egy ilyen kísérletet említenénk meg. Anne Buttimer szerint a humanisztikus földrajz által alkalmazott fenomenológiai módszer - ha nem is léphet a pozitív tudomány helyébe - ,a tudományos módszerek fontos preambulumának tekinthetö" (Buttimer 1976, 281). Mit is jelent a „preambulum" (,preamble”) kifejezés? A jogi szaknyelvben a törvények elé írt bevezető indoklást szokás preambulum néven illetni. Tuan még arról beszélt, hogy a humanisztikus felfogás egyes elemei „,beilleszthetők” (,,may be amenable”) a pozitivista saját módszertanába. A preambulum kifejezés ennél jóval óvatosabb: eszerint a fenomenológiai módszer csupán segítséget ad az objektív tudományoknak abban, hogy elkerülje a mindennapi tapasztalat világával való kritikátlan azonosulást. De miképpen?

\section{A strukturalista értelmezési keret}

A továbblépéshez mindenekelött a humanisztikus földrajz két kulcsfogalmára, a „hely”-re (place) és az ,identitás”-ra (identity) célszerü röviden reflektálni:

(a) Reflexió a ,hely" fogalmához. A humanista fenomenológiai módszerének célja, hogy hagyja a mindennapi földrajzi tapasztalatban konstituálódó „életvilágot” (Lebenswelt; lifeworld) a „saját fogalmai által megmutatkozni” (Buttimer 1976, 277). Ez úgy érhető el, hogy a közvetlen, mindennapi tapasztalatban átélt, térbelileg konstituálódó világ (benyomások, képzetek, emlékek és az ezektől nem függetleníthető cselekvések) minél gondosabb megfigyelése és leírása során a lehető legteljesebb mértékben felfüggesztjük az objektív tudomány elöítéleteit. Ha ennek során kifejezetten a térbeliség felől koncentrálunk, akkor máris megérkeztünk a humanisztikus földrajz egyik kulcsfogalmához, a ,hely”-hez (,place”). A hely még véletlenül sem azonosítandó az objektív „tér”-rel (,space”). A hely voltaképpen a személyesen megélt (megtapasztalt) tér, és mint ilyen eredendően szubjektív. A személyesség természetesen nem azt jelenti, hogy az individuumok mellett az emberek egy tetszőleges csoportjának, vagy akár egész közösségeknek ne lehetne saját helyük. A husserli eredetü, és Alfred Schütz által a szociológiában is meghonosított „interszubjektivitás” (intersubjectivity) fogalma alkalmas lehet arra, hogy a humanista az ilyesféle megosztott, közösségi jellegű helyeket is értelmezni tudja (Schütz 1970). Mindezek figyelembevételével a humanista megközelítése szerint hely lehet „bármely, személyek vagy személyek egy csoportja számára jelentöséggel bíró helyszín" (Tuan 1978, 13).

(b) Reflexió az ,identitás” fogalmához. Az identitás fontosságát a humanisztikus földrajz számára jól mutatja, hogy Anne Gilbertnek az új regionális földrajzról írott összefoglaló cikke (Gilbert 1988) egyenesen arról beszél, hogy a humanisztikus földrajz az új regionális földrajz nagy áramlatai közül ahhoz tartozik, amely regionális vizsgálatait valamiképpen az identitás fogalmára kívánja építeni. Az identitás ilyesfajta központi szerepe az előzőek fényében egyáltalán nem tekinthető meglepőnek. Induljunk ki abból, hogy magát az identitást a kortárs szociológia gyakran határozza meg a következőkhöz hasonlóan: ,identitáson, amennyiben ez társadalmi cselekvökre vonatkozik, olyan jelentést konstruáló folyamatot értek, amely egy 
kulturális sajátosságon, vagy kulturális sajátosságok egymással kapcsolatban lévő csoportján alapul, amennyiben ez(ek) a sajátosság(ok) más jelentésforrásokkal szemben prioritást élvez(nek)" (Castells 1997, 6). A konstrukciós folyamatra tett utalást egyelöre figyelmen kívül hagyva itt és most csupán annyit emeljünk ki, hogy az identitás az emberi szubjektumok vagy azok egy csoportja önmeghatározásának szempontjából prioritással bíró ,jelentés”-ek (,meanings”) minél gondosabb megfigyelésén és leírásán/megértésén keresztül közelíthető meg$^{2}$. Ha pedig a regionális identitást kívánjuk meghatározni, akkor azokig a jelentésekig célszerủ eljutnunk, amelyek alapján az emberi szubjektumok és/vagy csoportok magukat egy adott regionális egységhez tartozónak definiálják. És mivel ezeknek a jelentéseknek a megértése mindig egyet jelent annak megértésével, ahogy ezek az emberi szubjektumok és/vagy csoportok számára, azok mindennapi tapasztalatában konstituálódnak, az identitásnak az olyasfajta, látszólag objektív fogalmaknak a definíciójában is kulcsszerephez kell jutniuk, mint amilyen például a ,régió”.

Az imént vázolt fordulatot elsőként azoknak a francia geográfusoknak a példái szemléltethetik, akik ugyan az identitás fogalmából indulnak ki vizsgálataik során, de ennek elsődlegessége esetükben már kevéssé egyértelmü. Mindez már az eltérő fogalomhasználatban is megmutatkozik. Jellemző módon ezekben a munkákban a „hely” helyett már a „régiô” (région) kifejezés kerül előtérbe.

A régió jelentése természetesen leginkább annak függvénye, hogy mit jelent a különböző szerzők számára az identitás elsődlegessége. Egyesek még - szorosan kapcsolódva a humanisztikus megközelítésmódhoz - abból indulnak ki, hogy a különféle regionális egységeket (elsősorban természetesen: a régiót) föleg kulturális alapú identitásuk teszi régiókká. Armand Frémont régió-definíciója szerint például „a definíció, amelyhez kötődöm, az emberek által megélt régió definíciója, azaz egy definíció, amely egy olyasféle teret reprezentál, amelyben egy közösség él; ez a térben élö közösség (saját kifejezésemmel élve) egy úgynevezett kapcsolati hálóval másképpen: nagymértékben fragmentált helyek összességével - rendelkezik. Ez az összesség túllép az egyszerü geometriai, materiális összességen, ugyanis olyan pszichológiai értékeket is magában foglal, amelyeket ezek a terek a szóban forgó közösségben élő személyek által hordoznak." (Frémont 1979, 28) Márpedig a régiót a pszichológiai értékek segítségével definiálni vitathatatlanul a régió és a regionális identitás terének azonosítását (vagy legalábbis kvázi-azonosítását) jelenti. Az identitás elsődlegessége ebben az esetben tehát még kétségtelennek tünik.

Más szerzők ellenben már mintha hajlanának bizonyos külső (objektív) magyarázati sémák befogadására. Charles Ricq például a regionális identitást már csupán származtatja az egyéb, például történeti, politikai és kulturális jellegü tényezőkből: „ha részletesen elemzés alá vetjük a régiót, különféle történeti, politikai kulturális stb. jellegü kapcsolatokhoz jutunk. A regionális identitás jellemzöit ezeknek a különféle kapcsolatoknak a típusai fogják kijelölni." (Ricq 1982-83, 116) Megint mások maguk mutatnak rá egy egyoldalúan szubjektivista - vagyis a szélesebb értelemben vett „társadalmi gyakorlat”-ot (,pratique sociale”) elhanyagoló, etnokulturális jellegü - megközelítés tarthatatlanságára. Így Bernard Poche kritikus hangnemben 
jegyzi meg: „régóta mondják, az etnológia és a nyelvjáráskutatás által megnyitott különféle utak nem képesek [...] egymással kompatibilis határok kijelölésére [...] A kultúrába emiatt tehát bele kell sorolni más tényezöket is, mégpedig azokat, amelyek a valóságos tényezök társadalmi gyakorlata körül összpontosulnak. [...] A kutatóknak természetszerüleg el kell kötelezniük magukat, hogy ez a gyakorlat foglalja el elöfeltevéseikben a kiemelt pozíciót." (Poche 1983, 5)

Úgy tűnik tehát, hogy a Frémont után idézett szerzők már nem abszolutizálják a regionális identitás szerepét. Hiszen, amikor Ricq arról beszél, hogy „a régió mint 'totalitás' két dimenziót tartalmaz, az első a létéhez, az identitásához, a személyiségéhez, az egységéhez, a másik a szervezetéhez és a müködéséhez kapcsolódik" (Ricq 1982-83, 116), akkor inkább egyenrangúságot, mintsem aszimmetriát fedezhetünk fel a hagyományos, vidali emberföldrajzból kölcsönvett fogalmak (,être”, „,identité”, „personnalité”, , unité”) és a már inkább az új regionális földrajz társadalmi fordulatát tükröző fogalmak (,organisation”, ,fonctionnement”) között. A humanisztikus földrajzhoz viszonyítva a legnagyobb újdonságot minden bizonnyal ez a társadalmi fordulat jelenti. Az imént idézett szerzők ugyanis külső (objektív) magyarázati sémáikban már egyértelmüen - tudatos vagy kevésbé tudatos módon felhasználják a társadalomtudomány néhány nagyjelentőségű elméletét. Úgy is mondhatnánk, hogy hajlamosak elfogadni az identitás egy olyasfajta értelmezését, amit Castells definíciójának kapcsán már előrebocsátottunk: az identitás nem más, mint egy társadalmilag konstruált folyamat eredménye.

A francia szakirodalom kapcsán Guy di Méo elsősorban Pierre Bourdieu strukturalizmusának hatására mutat rá: „a jelenségek, amelyekhez az embertudományok kötödnek, a valódi és tényleges emberekhez kapcsolódnak, azokhoz, akik egy olyan adott történeti korban és társadalmi szervezetben élnek, [...] amely meghatározza viselkedésüket. Ezek az emberek sem nem tehetetlen tárgyak, sem nem olyan tiszta és transzcendentális alanyok, amelyek nincsenek a társadalmi törvények alá vetve. Egy komplex valóságot formálnak, elválaszthatatlanul tárgyak és alanyok. Így individuális szinten, a társadalmi közösséggel való kapcsolatukban válnak valóságossá, amit Pierre Bourdieu a 'külső valóság belsővé tétele' és a 'belső valóság külsővé tétele' dialektikájának nevez. Ez folyamatosan hozza létre az emberi tényezöt és - ebböl következöen - a térbeliség rendjét. Összességében, ha a társadalmi folyamat által megerösitett és módositott társadalmi struktúrák szabályozzák a szubjektivitás struktúráit, ez utóbbiak a maguk részéröl autonómmá válnak [...] és visszahatnak azokra a társadalmi struktúrákra, amelyeknek a stabilitása és a súlya bizonyos pillanatokban objektivitásuk illúzióját kelti bennünk. Márpedig, az efféle struktúrák sohasem megváltoztathatatlanok. Folyamatosan konstruálódnak, s a térben és az időben aktualizálódnak." (Di Méo 1996, 40-41) Bourdieu strukturalizmusa számunkra főként azért lehet fontos, mert anélkül teszi lehetővé a külső (objektív) magyarázati sémákra való hivatkozást, hogy fel kellene adnunk az „emberi tényező' (,l'ordre humain”, „human agency"), illetve az identitás kitüntetett szerepét. Úgy is mondhatjuk, a humanisztikus földrajz „humanizmusát” Bourdieu strukturalizmusának keretein belül sikeresen egyeztethetjük össze a társadalomtudományok „objektivizmusával”. 
Lényegében ezen az úton haladnak azok a többnyire angolszász kultúrkörben fogant elméletek is, amelyek Anthony Giddens strukturációelméletének hatása alatt fogalmazzák újra a regionális földrajz problematikáját a nyolcvanas évek elejétől kezdve. Giddens strukturációelmélete - Bourdieu strukturalizmusához hasonlóan az emberi tényező és a társadalmi struktúrák dialektikájára épül. Számunkra talán az az állítása a legfontosabb, hogy a társadalom időben és térben strukturálódik (Giddens 1985, 283). Mindebben jól felismerhető Throsten Hägerstrand az ember tér-idő koordináták közötti mozgásformáit leíró „időföldrajz”-ának (,timegeography”) hatása (Hägerstrand 1975), azonban Giddens a hägerstrandi premiszszák mellett természetesen saját szociológiai elméletének tanulságait is felhasználja. A térbeliség általa használt alapkategóriáján, a „színhely”-en (,locale”) így már nem a humanisztikus földrajz vagy a hägerstrandi időföldrajz szubjektív helyfogalmát, sokkal inkább az emberi szubjektumok/társadalmi cselekvők közötti interakciók olyan terét kell érteni, amelyek keretei között bizonyos alapvető társadalmi intézmények strukturálódnak. „A színhelyek a tér használatára utalnak a célból, hogy biztositsák az interakciók kereteit. Mindazonáltal ezeknek a kereteknek a sajátosságai, megszokott módon, az interakció szempontjából jelentéssel bíró tartalom konstrukciójára is felhasználhatók. A kontextus így az interakció legbensőbb és leginkább részletes elemeihez kapcsolja a társadalmi élet intézményesülésének tágabb sajátosságait." (Giddens 1985, 272-273) Giddens szerint a régió is egyfajta „színhely”, éppen ezért nem lehet csodálkozni azon, hogy az új regionális földrajz Giddens hatása alatt álló legfontosabb képviselöi, így Allan Pred, Nigel Thrift vagy Anssi Paasi maguk is a társadalmi interakciók ilyesfajta színhelyeként értelmezik a régió ${ }^{3}$ fogalmát. A következőkben mi csupán a régió fogalmának talán legszisztematikusabb elemzését adó finn Anssi Paasi munkásságára - illetve a régió történetiségére utaló megjegyzésére - fogunk röviden kitérni.

Eszerint Paasinál a régió ,, a 'longue durée' egy intézményes szférája, amely a társadalom térbeli struktúrájának egy specifikus dimenzióját jeleníti meg. Bár a régió a társadalmon belül egy véletlenszerü történelmi folyamatnak tekinthetö, [...] a társadalomban betöltött intézményes szerepének következtében egy tartósabb struktúrában nyilvánul meg." (Paasi 1986, 114) Vagyis a régió meghatározásához elsösorban az úgynevezett társadalmi intézményeket kell figyelembe vennünk. A társadalmi intézmények - vagy ami Paasinál ugyanazt jelenti, bizonyos tipizált cselekvésformák - azért tekinthetők intézményeknek, mert függetlenednek ettől vagy attól a cselekvéstől, ami viszont a történeti dimenzió felé vezet minket. A társadalmi intézményeknek ugyanis, eltérően az egyedi, tipizálatlan cselekvésektöl, történetiségük van, amely a régiót egy tartós létezési formával ruházza fel. Ez persze a giddensi strukturációelmélet hatása alatt álló Paasinál sem jelenti az emberi tényező társadalmi struktúráknak való egyoldalú alárendelődését. Számára a régió inkább „egy folyamat eredménye, amely által a társadalmi struktúrák és a cselekvők közötti interakciók szándékolt cselekvések következményeképp régiókat hoznak létre" (Paasi 1986, 114). 
Az intézményesülés során minden régió szert tesz:

1) egy „területi formára” (,territorial shape”), amely lényegében a régiót egyéb régióktól elválasztó határok segítségével adható meg;

2) egy „szimbolikus formára” (,symbolic shape”). Leginkább régió neve és a legkülönfélébb egyéb regionális szimbólumok tartoznak ebbe a kategóriába;

3) egy „intézményes formára” (,institutional shape”). Azok a társadalmi intézmények tartoznak ide, amelyek nélkülözhetetlenek a területi forma és a szimbolikus forma fenntartásához, másképpen: a régió létéhez;

4) és, ami számunkra a legfontosabb, az úgynevezett „elfogadott identitásra” (,established identity”), amelyre a régió a különféle társadalmi intézményeken és a regionális tudaton keresztül tesz szert mind a régión belül, mind pedig azon kívül.

\section{A történetiség hozzájárulása értelmezésünkhöz}

Paasi tehát „,tartós” (,permanent”) létezési formával ruházza fel a régiót. Mivel a régiót leginkább a stabilitás, a változatlanság és az állandóság fogalmainak segítségével kívánja megragadni, szinte magától értetődő módon rendeli alá a régió léte szempontjából releváns társadalmi intézményeket a „,hosszú időtartam” (,longue durée") braudeliánus fogalmának. A kifejezés eredetileg a vidali örökség keretében fogant. A francia emberföldrajz alapító atyja, Paul Vidal de la Blache elemzései során ugyanis bizonyos változékonyabb, illetve tartósabbnak tekinthető emberi aktivitásformákat különített el egymástól. Ez pedig - Krzysztof Pomian szavaival - annyit jelent, hogy egy „nagy jövő elé néző megkülönböztetést elölegezett meg: a rövid, illetve a hosszú időtartamét” (Pomian 1997, 915). A „hosszú időtartam” fogalmának explicit használatát, illetve strukturalista keretek közé helyezését azonban Fernand Braudel nevéhez kell kötni. Hasonló címü cikkében a következőképpen ír erről: „Bizonyos struktúrák stabil elemekké válnak generációk végtelen során keresztül. Ezek akadályozzák a történelmet, megakasztva, tehát uralva a dolgok folyását. Mások sokkal gyorsabban morzsolódnak szét. [...] Mindannyian támasztékok és gátak. [...] Gondoljunk bizonyos földrajzi keretek, bizonyos biológiai adottságok, bizonyos termelési lehetöségek, sőt mi több, ilyen vagy olyan spirituális kényszerek áthágásának nehézségeire: a mentális keretek szintén a hosszú idötartam börtönei.” (Braudel 1958, 731) Braudel tehát a generációk hosszú során keresztül is stabilnak tekinthető struktúrákat utalja a hosszú időtartam fogalomkörébe, élesen szembeállítva azokat a „rövid időtartam” (,courte durée”) kevéssé stabil struktúráival. Bár az iménti idézet mintha a hosszú időtartamhoz kötődő struktúrák valamiféle kitüntetett szerepét sugallná a történeti vizsgálódások keretei között - hiszen ne feledjük: a legstabilabb, következésképp a legnehezebben áthágható struktúrákról van szó -, ez azonban már Braudelnél sem azt jelenti, hogy valamiféle kizárólagosságra tennének szert. Épp ellenkezőleg: pár oldallal később egyértelműen kijelenti: „a történelem minden lehetséges történelem összessége" (Braudel 1958, 734). 
S hogy mit jelenthet ez a különféle regionális egységek szempontjából? Elsősorban azt, hogy Paasi értelmezése - már ha az ott szereplő longue durée kifejezést többnek kívánjuk tekinteni egyszerü metaforánál - még Braudelnél is „braudeliánusabb”. Másképpen: mintha csak azokat a társadalmi intézményeket tekintené relevánsnak a régió létének szempontjából, amelyek valamiképpen a hosszú időtartam struktúráiból származtathatók. Márpedig egyáltalán nem tünik szerencsésnek, ha egy adott térbeli egység létét csupán egyfajta időbeliség eredményének tekintjük. Lényegében így érvel a neves svájci geográfus, Jean-Luc Piveteau, aki - kissé metaforikus módon ugyan, de igen szemléletesen - az egy adott időpillanatban megfigyelt teret a különféle időbeliségek eredője által meghatározottnak, azok egyfajta „,palimpszeszt'-jének és/vagy ,,keresztmetszeti vetület’-ének értelmezi: „, a tér szervezödése egy adott pillanatban [...] egyszersmind palimpszeszt, 'keresztmetszeti vetület', amelyet igen nagyszámú ritmus müködtet. Épitoő és/vagy romboló ritmusok, a felépítettség egy bizonyos szinten általában együtt jár egy ezt kísérö leépítettséggel egy másik szinten; ciklikus ritmusok és/vagy egy bizonyos irányultsággal rendelkezö tendenciák (azaz visszafordíthatatlanok - egyelöre visszafordíthatatlanok); rövid ritmusok, átlagos ritmusok, végül, de nem utolsósorban, hosszú és nagyon hosszú ritmusok. A rövid időhöz kötödö tendenciák vagy egy olyan mozgást jelenítenek meg, amely hosszabb idötartamokba tolódik bele, vagy pedig egy független és önmagában álló folyamatot testesít meg." (Piveteau 1990, 211)

Ha a számunkra ismerős strukturalista értelmezési keretben mozgunk, akkor azt kell mondanunk, hogy ezeket a különféle időbeliségeket különféle társadalmi intézmények konstruálják. Ezek közül egyesek meglehetősen stabilak, más struktúrák ezeknél kétségkívül törékenyebbek. Ezt a törékenységet csak első pillantásra tünhet helyesnek oly módon kiküszöbölni, ha a rövidebb időtartamokhoz kötődő, esetlegesebb struktúrákat stabilabb struktúrákra vezetjük vissza. A történetelmélet legújabb eredményeinek - főleg a káoszelmélet történetírói praxisra való alkalmazásának - fényében ugyanis egy efféle stratégia nemigen tủnik kivitelezhetőnek. A társadalomtudományokban leginkább ,pillangó-hatás”-ként ismeretes jelenség legfontosabb következménye az, hogy a rövid időtartam leginkább esetleges változásai is döntően tudják befolyásolni (átformálni) a komplex rendszerként felfogott regionális egység jövőjét (Reisch 1997). Ezért is tünhetnek a forgalomban lévő régió-definíciók valamilyen szempontból egytöl-egyig tökéletlennek; hiszen a „mi teszi ezt a regionális egységet egy koherens regionális egységgé?” kérdésre adott válasz teljesen eltérö lehet attól függően, hogy a különféle egyedi esetekben mely időbeliségek szerepe a leghangsúlyosabb. Ezek skálája a hosszú időtartamhoz köthető struktúráktól a szinte már véletlenszerünek tetsző eseményekig terjedhet. Ha tehát bizonyos sajátosságok nem magyarázhatók az úgynevezett tartósabb struktúrák segítségével, akkor - ahelyett, hogy egyszerű anomáliákként kezelnénk őket, s a továbbiakban nem vennénk tudomást róluk - az időbeliségek pluralitásának egyidejű figyelembevételére, végeredményben az eseti történeti leírás módszerére célszerü áthelyezni a hangsúlyt. 
Egy konkrét példa: a „kistérség” definíciója

A kortárs regionális diskurzus általában evidenciaként kezeli a regionális szintek sokféleségét. A regionális szintek sokféleségéből azonban magától értetődő módon következik az is, hogy az intézményesülés a különféle regionális szintek esetében nem pontosan ugyanazt jelenti. A neves francia geográfus, Jacques Lévy hierarchikus térfelosztása (Lévy 1996) jó kiindulópontul szolgálhat a probléma kifejtéséhez. Ennek megalkotásakor a szerző különös figyelmet fordított a hägerstrandi időföldrajz tanulságaira, amely jelen esetben az ember tér-idő koordináták közötti mozgásformáinak hierarchizálását jelenti. A modell alapvető hierarchiaszintjeinek a „kontextuális” („,contextuel”), illetve a „referenciális” („référentiel”) szintek tekinthetők. A kontextuális szint Jacques Lévy szerint „,az ott található individuumok életének egy konkrét és sokdimenziós keretét rögziti"', és két további alszintre bontható, nevezetesen a „lokális szint”-re („l'échelle locale”) és a „regionális szint”-re („l'échelle régionale”) (Lévy 1996, 383).

A lokális szint ,az egyetlen olyan szintet jeleníti meg, ahol a mindennapiság lehetséges: azt, hogy mi mindennek kell körülbelül minden nap megtörténnie ahhoz, hogy jelentést nyerjen az, ami ott kibontakozhat. Ez a szint kölcsönös átjárhatóságot foglal magában az ebben a térben lévö helyek között, és nem csupán a lakóhelyi és munkakapcsolatokat, hanem más mindennapi mozgásformákat is: a 'helyi ügyek' intézését, a kereskedelmet, a szabadidőt, a személyes kapcsolatokat." (Lévy 1996, 383) A regionális szint ezzel szemben „mint életrajzi szintü létezö a legkisebb tér, amelyhez minden olyan strukturális foglalatosság (képzés, munka, kultúra, személyközi kapcsolatok, állampolgárság) hozzákapcsolható, amellyel egy individuumnak kell tudni rendelkeznie az élete folyamán". (Lévy 1996, 383). Vagyis többnyire kontextuális szinten mennek végbe a társadalmi cselekvők mindennapi (lokális), valamint életrajzi szintü (regionális) mozgásformái, szembeállítva azokat az úgynevezett referenciális szinttel - ez utóbbiba sorolható például a ,nemzeti” (,,nationale”), ,zonális” (,zonale”), vagy „globális" (,,mondiale”) szint -, amelyek elképzelt közösségei sokkal kevésbé kötődnek konkrét életvilágunkhoz, s inkább egy szélesebb politikai, kulturális stb. diskurzus konstrukciós folyamatának eredményével hozhatók kapcsolatba.

A ,mindennapi”, illetve az ,életrajzi” szinthez sorolható mozgásformák között természetesen létezhetnek, $\mathrm{s}$ léteznek is átmeneti kategóriák. $\mathrm{S}$ itt érdemes lehet kitérni a hazai gyakorlat egy problematikusnak minősíthető regionális szintjének, az úgynevezett ,kistérségi szintnek” a definíciójára. Annyit feltétlenül tudunk, hogy a kistérség valahol a településszint (a NUTS 5/LAU 2) és a megyei szint (NUTS 3) között helyezkedik el, arról azonban, hogy mit is jelent pontosan az intézményesülés a kistérség esetében, az eddigiek ismeretében nem szabad elhamarkodottan nyilatkoznunk.

A rendszerváltást követő közigazgatási-területfejlesztési diskurzus ráadásul inkább elbizonytalaníthat bennünket e tekintetben. Az 1996. évi XXI. tv. 5. §. h. pontjának eredeti megfogalmazása szerint a kistérség ,a települések között létezö funkcionális kapcsolatrendszerek összessége alapján behatárolható területi egység, 
egymással intenzív kapcsolatban lévő, önszerveződő, egymással határos települések összessége". A definícióban azonban egy látható inkonzisztencia mutatkozott meg. A ,funkcionális kapcsolatrendszerek összessége alapján behatárolható” kitételben a Központi Statisztikai Hivatal (KSH) 1992-1993 során kialakított és 1994. január 1-jén hatályba léptetett statisztikai kistérségi rendszerének központilag definiált és meghatározott, úgy is mondhatnánk: „objektivista” módon definiált kistérségei köszöntek vissza, míg az „önszerveződő’ kifejezés az akkori alulról építkező társulási formákra utalt. Az inkonzisztencia eltüntetése az alulról építkező kistérségi szerveződéseknek a statisztikai kistérségek rendszeréhez való hozzáigazítása révén valósult meg. A 244/2003. (XII. 18.) Korm. Rendelet, 1 (1-2) bekezdése már kihagyta az önszerveződésre való hivatkozást a kistérség definíciójából, a települési önkormányzatok többcélú kistérségi társulásáról szóló 2004. évi CVII. törvény pedig a mindenkori éves költségvetési törvényben elkülönített támogatás indirekt ösztönzésének eszközét felhasználva tulajdonképpen be is fejezte a hozzáigazítást: a többcélú kistérségi társulások rendszere a 2005. évtől kezdve nagyjából-egészében általánossá vált.

A többcélú kistérségi társulások preferálása azonban felveti a kistérségi szint egyéb, alulról építkező formái elsorvasztásának veszélyét. Az „újrakörzetesítés” rémképének felemlegetése helyett (Szelényi-Ladányi 2005) azonban mi inkább arra hívnánk fel a figyelmet, hogy a központilag definiált és lehatárolt versus alulról építkezö kistérségek alternatív megközelítését inkább kibékíteni kellene egymással. S ezt talán már a 2004. évi CVII. törvény sem tenné lehetetlenné. Egyrészről, mivel a többcélú kistérségi társulások döntéshozó szervében, az úgynevezett társulási tanácsokban az illető kistérség önkormányzatainak polgármesterei vesznek részt, ez a társulási forma felfogható egyfajta speciális önkormányzati társulásként is. Másrészről, a törvény arra is elvi lehetőséget ad, hogy a települési önkormányzatok képviselőtestületei az önkormányzati választásokat követő hat hónapon belül az illetékes minisztériumnál kezdeményezhessék egy másik statisztikai kistérségbe való átsorolásukat. ${ }^{4} \mathrm{~A}$ helyi érdekek érvényesülésére tehát a hatályos szabályozás keretei között is lehetőség van/lenne. Ehhez viszont feltétlenül újra kell gondolnunk a kistérség definícióját, mégpedig az alábbiak figyelembevételével:

a) El kell kerülnünk az általunk keresett kistérség-fogalom többcélú kistérségi társulásokkal való kritikátlan azonosítását. Hiszen ez a humanisztikus preambulumnak az aktuális közigazgatási-területfejlesztési diskurzus nevében történő negligálását jelentené. A kistérség definíciójának újragondolása során a helyi társadalom identitásalakzatainak, illetve - ezzel párhuzamosan - a mögöttük álló konkrét mozgásformák (társadalmi intézmények) feltárása lehet az első lépés.

b) Noha csábító lenne a kistérségi szintet mindenestül a helyi társadalom konkrét mozgásformáinak segítségével definiálni, ebben az esetben igencsak mereven járnánk el. A kistérség helyes megközelítése során feltétlenül ki kell tágítanunk a „,szereplők" kifejezés mögött álló jelentéstartalmakat a referenciális szint felé: nem csupán a helyi társadalom perspektívájára, hanem a mindenkori közigazgatásiterületfejlesztési diskurzus tágabb (nemzetállami és/vagy uniós) kontextusára, illetve annak a helyi társadalomra gyakorolt hatására is tekintettel kell lennünk. 


\section{Jegyzetek}

${ }^{1}$ A szó szerinti idézetek fordításait a szerző készítette.

${ }^{2}$ Humanisztikus keretek között mozogva egyelöre még szerencsésebbnek tủnik az „emberi szubjektum” kifejezést használni az objektív társadalom létét már előfeltételező „társadalmi cselekvő” kifejezés helyett. ${ }^{3}$ Prednél kivételesen még: a hely.

${ }^{4}$ A végső döntést persze ezekben az esetekben is az Országgyülés hozza meg, mégpedig a szakértőkkel konzultáló kormány előterjesztése alapján. A helyi szereplök lehetőségei tehát ezután is kimerülnek a javaslattételben, s érdekeiket valójában legfeljebb a döntéshozók felé irányuló lobbytevékenység révén érvényesíthetik.

\section{Irodalom}

Braudel, F. (1958) Histoire et sciences sociales. La longue durée. - Annales. Économies, Sociétés, Civilisations. 4. 725-753. o.

Buttimer, A. (1976) Grasping the dynamism of lifeworld. - Annals of the Association of American Geographers. 2. 277-292. o.

Castells, M. (1997) The Information Age: Economy, society and culture. Volume II. The Power of Identity. Blackwell, London.

Di Méo, G. (1996) Â la recherche des territoires du quotidien. - Di Méo, G. (ed.) Les territoires du quotidien. L'Harmattan, Paris. 35-48. o.

Entrikin, J.N. (1976) Contemporary humanism in geography. - Annals of the Association of American Geographers. 4. 615-632. o.

Frémont, A. (1979) A chacun sa définition. - Espaces Temps. 10-11. 27-29. o.

Giddens, A. (1985) Time, space and regionalisation. - Gregory, D.-Walford, R.(eds.) Social Relations and Spatial Structures. Macmillan, London. 265 -295. o.

Gilbert, A. (1988) The new regional geography in English and French-speaking countries. - Progress in Human Geography. 1. 209-228. o.

Gregory, D. (1994) Humanistic Geography. - Johnson, R.J.-Gregory, D. (eds.) The Dictionary of Human Geography. Blackwell, London. 263. o.

Hägerstrand, Th. (1975) Space, time and Human Conditions. - Karlquist, A.-Lundquist, L.-Snickars, F. (eds.) Dynamic Allocation of Urban Space. Saxon House, Farnborough. 3-12. o.

Lévy, J. (1996) Territoires et résaux. - Thiery Paquot (ed.) Le monde des villes. Panorama urbain de la Plànete. Complexe, Paris. 375-389. o.

Paasi, A. (1986) Institutionalization of regions: a theoretical framework for undesstanding the emergence of regions and the constitution of regions and the constitution of regional identity. - Fennia. 1. 105-146. o.

Pickles, J. (1985) Phenomenology, science and geography. Spatiality and the human sciences. University Press, Cambridge.

Piveteau, J-L. (1990) L'épaisseur temporelle de l'organisation de l'espace: ,palimpseste” et „,coupe transversale”. GEOPOINT 90. Histoire, temps et espace. Groupe Dupont Université d'Avignon. 211-220. o.

Poche, B. (1983) La région comme espace de référence identitaire. - Espaces et Sociétés. 1. 3-12. o.

Pomian, K. (1997) L'heure des Annales. La terre - les hommes - le monde. - Nora, P. (ed.) Lieux de Mémoire 1. Éditions Gallimard, Paris. 903-952. o.

Reisch, G.A. (1997) Káosz, történelem és elbeszélés. - Fokasz N. (szerk.) Rend és káosz. Fraktálok és káoszelmélet a társadalomkutatásban. Replika Kör, Budapest. 117-137. o.

Ricq, Ch. (1982-83) La région, espace institutionnel et espace d'identité. I-II. - Espaces et Sociétés. 2. ill. 1. 113-129. o., 65-78. o.

Schütz, A. (1970) The problem of Racionality in the Social World. - Emmet, D.-Macintyre, A. (eds.) Sociological Theory and Philosophical Analysis. Macmillan, New York. 89-114. o.

Szelényi I.-Ladányi J. (2005) Az újrakörzetesítés társadalmi ára. - Kritika. 1. 5-7. o.

Tuan, Y.-F. (1977) Space and Place: Humanistic Perspective. - Gole, S.-Olsson, G. (eds.) Philosophy in Geography. D. Reidel Publishing Company, Dordrecht. 387-428. o.

Tuan, Y.-F. (1978) Space, time, place. A humanistic frame. - Carlstein, T.-Parkes, D.-Thrift, N. (eds.) Making Sense of Time. Edward Arnold, London. 7-16. o. 


\section{A STRUCTURALIST APPROACH OF THE REGIONAL IDENTITY}

\section{TIBOR LÁSZLÓ BUSKÓ}

In the study the author makes an attempt at give some theoretical reflexion on the definition of region. He sets out from the humanistic geography that tries to understand the region in a subjective way, by means of the regional identification. However, the author's purpose is to go on towards a more complex approach emerged from English and Frenchspeaking new regional geography from the 1980s. According to this approach, inspired by the socio-structural theories of Pierre Bourdieu and Anthony Giddens, the simplifications of humanism (i. e. over-emphasizing of the regional identity) can be replaced by a dialectic of the 'subjective' and 'objective' factors. After elaborating this structuralist approach the study demonstartes that some practical problems of Hungarian regional discourse (e. g. the absence of an adequate definition of microregions) can be resolved by it, too. 